\title{
Angiomyofibroblastoma of the uterine cervix in a patient with triple negative breast cancer: a case report
}

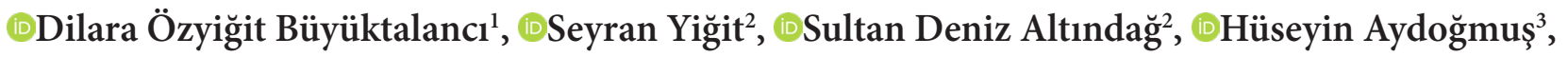 \\ ๑DServet Gençdal ${ }^{3}$ \\ ${ }^{1}$ Ege University Faculty of Medicine, Department of Pathology, Izmir, Turkey \\ ${ }^{2}$ Katip Celebi University Ataturk Training and Research Hospital, Department of Pathology, Izmir, Turkey \\ ${ }^{3}$ Katip Celebi University Ataturk Training and Research Hopital, Department of Gynaecology and Obstetrics, Izmir, Turkey
}

Cite this article as: Özyiğit Büyüktalancı D, Yiğit S, Altındağ SD, Aydoğmuş H, Gençdal S. Angiomyofibroblastoma of the uterine cervix in a patient with triple negative breast cancer: a case report. Anatolian Curr Med J 2021;3(2); 181-184.

\begin{abstract}
Angiomyofibroblastoma is an uncommon, benign mesenchymal tumor which generally occurs in the vulvovaginal region. Uterine cervix localisation is uncommon. A 40-year-old female patient, who had been operated becasue of breast carcinoma, presented vaginal bleeding. Examination revealed a polypoid mass located in both vagina and cervix. She underwent total abdominal hysterectomy and bilateral salpingectomy. With the help of typical histopathology and immunohistochemical findings, a diagnosis of "angiomyofibroblastoma" was made. Angiomyofibroblastoma is a benign mesenchymal tumor of unknown pathogenesis. A recognition of this entity is important to avoid misdagnosis of other angiomyxoid neoplasms such as aggressive angiomyxoma.
\end{abstract}

Keywords: Angiomyofibroblastoma, cervix uteri, breast carcinoma

\section{INTRODUCTION}

Angiomyofibroblastoma (AMFB) is characterized myofibroblastic differentiation and neoplastic stromal cell proliferation (1). AMFB is usually seen perineal and vulva-vaginal region in females and scrotum in males (2). AMFB needs to be distinguished from other stromal tumors especially angiomyxoma which is aggresive behaviour (3). Uterine cervix localization is unexpected in this tumor. To the best of our knowledge, 5 cases have been reported and this is the second reported AMFB of the uterine cervix in a patient with breast cancer in English literature $(1,2,4-6)$. Tamoxifen treatment is thought to be effective in the development of AMFB (7). In this report, we discussed the histogenesis, immunohistochemical features, differential diagnosis, and relationship with tamoxifen of this uncommon entity and reviewed the English literature.

\section{CASE REPORT}

A 40-year-old female patient admitted to the hospital with vaginal bleeding. In medical history, she had a triple negative invasive ductal breast carcinoma which was treated with conservative breast surgery with axillary dissection and adjuvant chemo and radiotherapy in 2007. The gynecologic examination revealed a polypoid mass located in both vagina and cervix. The patient was diagnosed with cervical leiomyoma and underwent total abdominal hysterectomy and bilateral salpingectomy $(\mathrm{TAH}+\mathrm{BS})$ and sent intraoperative consultation. Macroscopically, TAH + BS was $10 \times 6 \times 4 \mathrm{~cm}$ size and a welldefined mass which was $6 \times 5 \mathrm{~cm}$ in size was detected in the posterior cervix. The mass cut surface was solid and light yellow in appereance Figure 1. As a result of intraoperative consultation, the mass was reported as a benign mesenchymal tumor except leiomyoma. Histologically, the tumor was characterized by hypocellular edematous areas mixed with thin walled small blood vessels. The tumor cells were uniform eosinophilic, spindle-shaped or epitheloid without mitotic figures or atypia (Figure 2-3). The immunohistochemistry tumor had shown a strong positivity with desmin, vimentin, estrogen receptor (ER), progesterone receptor (PR), focal positivity with CD117 and caldesmon but $\mathrm{CD} 34$ and smooth muscle actin (SMA) were negative. According to these findings, the tumor was diagnosed as a "angiomyofibroblastoma". No tumor recurrence was reported. 


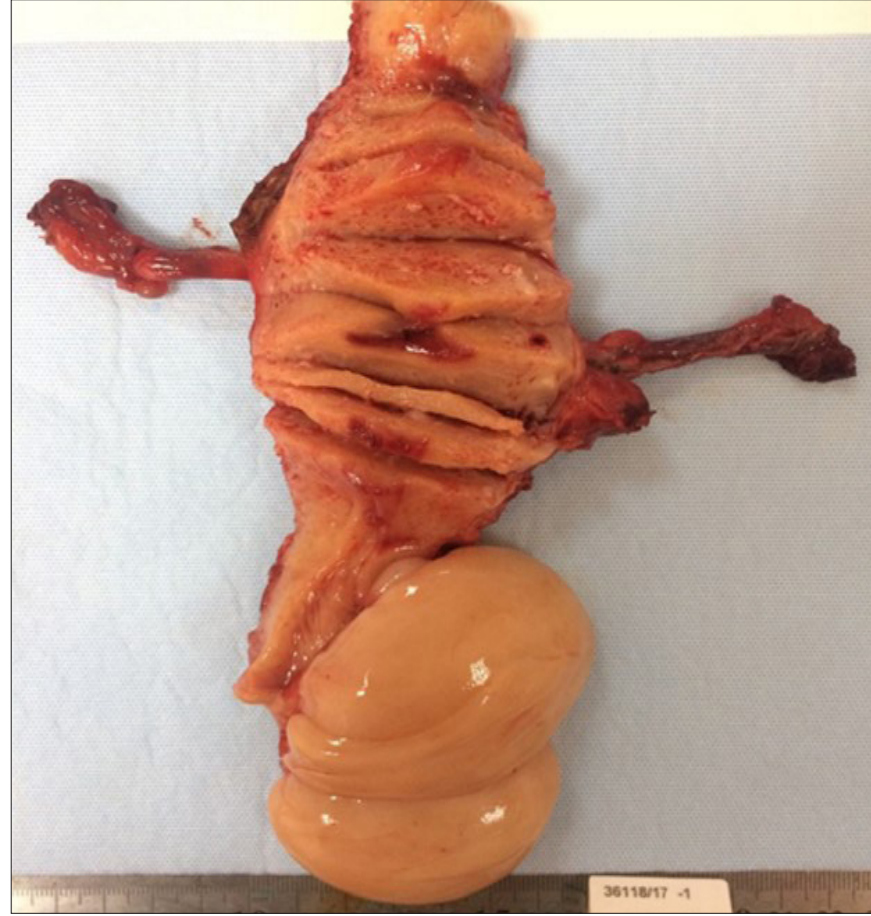

Figure 1. A well-defined mass which was $6 \times 5 \mathrm{~cm}$ in size was detected in the posterior cervix

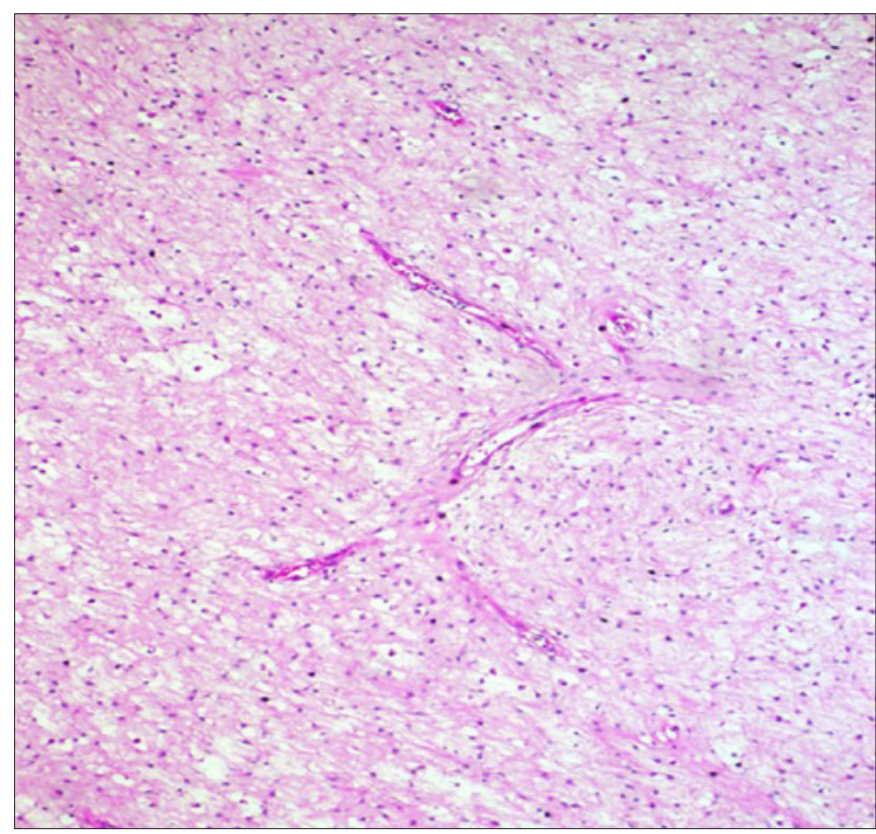

Figure 2. Tumor composed of hypocellularity in oedematous stroma and thin-walled blood vessels H\&E x100

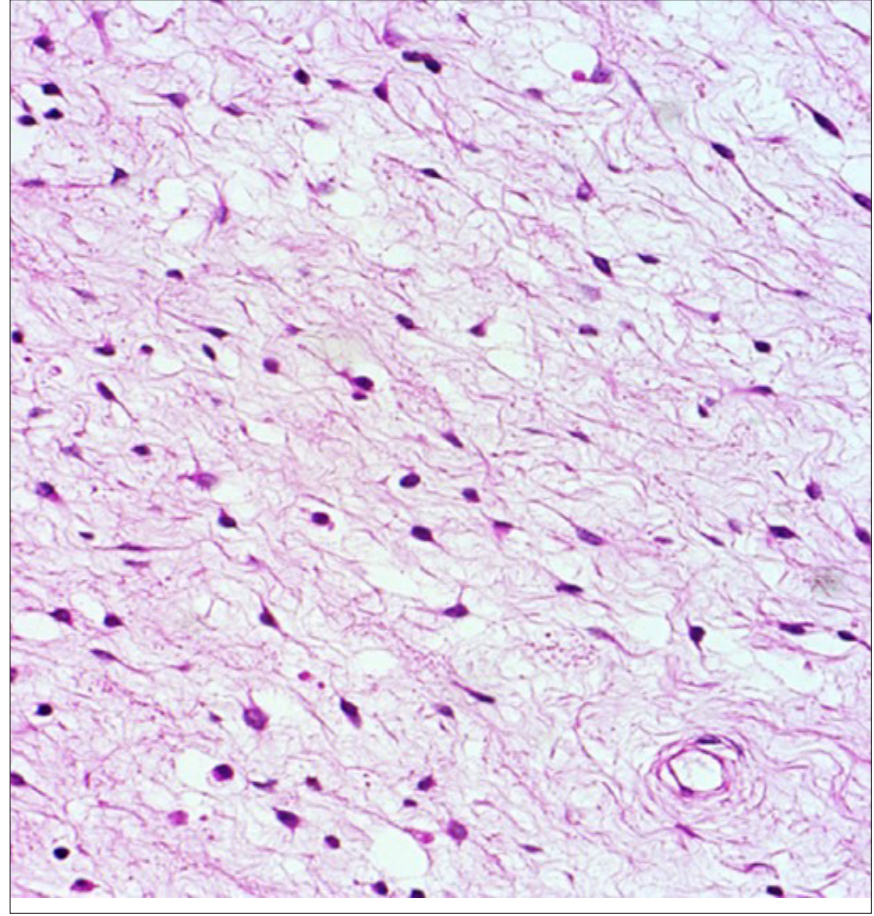

Figure 3. The neoplastic cells are bland-looking, spindle or oval shaped with scanty cytoplasm. H\&E x400

\section{DISCUSSION}

Angiomyofibroblastoma is frequently seen in vulva and vagina and between the ages of 20-50 $(4,5)$. However, there are unusual cases reported in males $(4,8)$. AMFB of the cervix is rarely seen with only 5 reports so far, ages range from 32- 53 and our case is 40 yearsold $(1,2,4-6)$. The clinical and pathological features of AMFBs seen in cervix localization are shown in Table 1.

The tumor size varies between $10-40 \mathrm{~mm}(1,6)$. In our case, the tumor was the biggest diameter of $60 \mathrm{~mm}$. Histologically, AMFB is characterized by variable hypocellular and hypercellular regions with spindle and round shaped cells $(3,7)$. Stromal cells tend to collect around vessels. The immunohistochemistry shows strong positivity with desmin, vimentin, ER, PR, focal positivity with SMA and S100 protein, and negativity with cytokeratin and myoglobin $(4,5)$. The imunohistochemical features of the cervical AMFB cases seen are listed in Table 2.

\begin{tabular}{|lccccc|}
\hline \multicolumn{4}{|l}{ Table 1. The clinical and pathological features of AMFBs seen in cervix localization } & & \\
\hline Case Number & Age (Years) & Clinical Presentation & Treatment & Tumor size (cm) & Referance \\
\hline 1 & 53 & Vaginal mass & Local excision & $4 \times 3$ & Lee CL et al. (1) \\
$2^{*}$ & 43 & Asymtomatic cervical mass & Local excision & $3 \times 3 \times 2.5$ & Min Ji Kim et al. (2) \\
3 & 44 & Polypoid mass & N/A & 2 & Babala et al. (4) \\
4 & 32 & Vaginal spotting & N/A & 1.2 & Y.P.Wong et al. (5) \\
5 & 48 & Intermens spotting & Cone biopsy & Roncati et al (6) \\
$6^{*}$ & 40 & Vaginal bleeding & TAH+BS & $6 \times 5$ & Present case \\
\hline${ }^{*}$ breast carcinoma history cases, N/A: Not available, TAH+BS: Total abdominal hysterectomy and bilateral salpingectomy & & \\
\hline
\end{tabular}




\begin{tabular}{|c|c|c|c|}
\hline $\begin{array}{c}\text { Case } \\
\text { Number }\end{array}$ & Positive IHC & Negative IHC & Referance \\
\hline 1 & $\begin{array}{l}\text { Desmin } \\
\text { CD } 34 \\
\text { SMA }\end{array}$ & N/A & Lee CL et al. (1) \\
\hline 2 & $\begin{array}{l}\text { Desmin } \\
\text { Vimentin }\end{array}$ & $\begin{array}{l}\text { CD34 } \\
\text { SMA }\end{array}$ & Min Ji Kim et al. (2) \\
\hline 3 & $\begin{array}{l}\text { Desmin } \\
\text { Vimentin } \\
\text { CD44 }\end{array}$ & $\begin{array}{l}\text { Ki67 } \\
\text { Sarkomeric } \\
\text { actin }\end{array}$ & Babala et al. (4) \\
\hline 4 & $\begin{array}{l}\text { ER } \\
\text { PR }\end{array}$ & $\begin{array}{l}\text { CD34 } \\
\text { Desmin } \\
\text { S100 }\end{array}$ & Y.P.Wong et al. (5) \\
\hline 5 & $\begin{array}{l}\text { SMA } \\
\text { Desmin } \\
\text { ER } \\
\text { PR }\end{array}$ & $\begin{array}{l}\text { CD34 } \\
\text { C Kit }\end{array}$ & Roncati et al. (6) \\
\hline 6 & $\begin{array}{l}\text { Desmin } \\
\text { Vimentin } \\
\text { ER } \\
\text { PR }\end{array}$ & $\begin{array}{l}\text { CD34 } \\
\text { SMA }\end{array}$ & Present case \\
\hline
\end{tabular}

The most important differential diagnosis is aggressive angiomyxoma (AAM). Other entities that should be considered in the differential diagnosis include cellular angiofibroma (CA), superficial myofibroblastoma (SM) fibroepithelial stromal polyp (FSP) (9). The clinical, histopathological, and immunohistochemical features of AMFB and differantial diagnosis are listed in the Table 3.
Aggressive angiomyxoma (AAM), described in 1983 by the first Steeper (4) and Rosai (9). AAM, with a high risk of recurrence, usually shows infiltrative growth with entrapped muscles, nerves, and mucous glands $(5,10)$. AMFB has well circumscipred and benign clinical course. AAM is consisted of bland-looking stellate tumor cells with myxoid stroma, which has numerous variable-thickness blood vessels in contrast AMFB higher cellularity more numerous blood vessels more frequent plump, spindle shape cells (5). Dispersed inflammatory cells, especially neutrophils are always present (4). Immunohistochemistrically, AMFB and AAM express similar markers (5). Unlike $A M F B$, the CA occurs as a small and well-defined mass, grossly. The tumor consists of bland spindle cells arranged in intersecting fascicles mixed with wispy collagen bundles and hyalinised thickwalled blood vessels $(4,5)$. CA is negative for desmin, and expresses variable estrogen receptor (ER), progesterone receptor (PR), CD34 and SMA (5). Superficial myofibroblastoma (SM) is composed of bland stellate or ovoid cells, within edematous and myxoid stroma $(5,11)$. The neoplastic cells are separated by a nonneoplastic stromal band (Grenz zone) (5). SM shows variable immunoreactivity for $\mathrm{ER}, \mathrm{PR}, \mathrm{CD} 34$, desmin, and SMA $(5,11)$. Fibroepithelial stromal polyp (FSP) is specific to the vulvovaginal region which is often incidentally encountered as a pedunculated polyp (5). It is overlied by squamous epithelium and typically contains central fibrovascular core (5).

Table 3. The clinical, histopathological, and immunohistochemical features of AMFB and differantial diagnosis.

\begin{tabular}{|c|c|c|c|c|c|}
\hline & AMFB & AAM & CA & SM & FSP \\
\hline Age (Years) & $20-50$ & $20-50$ & Middle-aged & $40-70$ & Reproductive age \\
\hline Clinical presention & Painless mass & Slow growing mass & Painless mass & Painless Mass & Asymptomatic \\
\hline Tumor size $(\mathrm{cm})$ & $<5 \mathrm{~cm}$ & $>10 \mathrm{~cm}$ & $2-3 \mathrm{~cm}$ & $<5 \mathrm{~cm}$ & $1-3 \mathrm{~cm}$ \\
\hline Margin & Well circumscipred & Infiltrative & Well circumscipred & Well circumscipred & Polypoid \\
\hline \multirow{3}{*}{ Histological features } & $\begin{array}{l}\text { Alternating zone of } \\
\text { cellularity }\end{array}$ & $\begin{array}{l}\text { Bland-looking } \\
\text { stellate-spindle cells } \\
\text { Myxomatous stroma }\end{array}$ & $\begin{array}{l}\text { Bland spindle cells } \\
\text { Collagen bundles }\end{array}$ & \multirow{3}{*}{$\begin{array}{l}\text { Bland stellate-ovoid } \\
\text { cells } \\
\text { Edematous or myxoid } \\
\text { stroma (Grenz zone) }\end{array}$} & \multirow{3}{*}{$\begin{array}{l}\text { Overlied squamous } \\
\text { epithelium } \\
\text { Central fibrovascular } \\
\text { core }\end{array}$} \\
\hline & Stromal cells around & $\begin{array}{l}\text { Variable thickness } \\
\text { blood vessels }\end{array}$ & \multirow[t]{2}{*}{$\begin{array}{l}\text { Hyalinised thick } \\
\text { walled blood vessels }\end{array}$} & & \\
\hline & & Inflammatory cells & & & \\
\hline Positive IHC & $\begin{array}{l}\text { Desmin } \\
\text { Vimentin } \\
\text { ER, PR } \\
\text { Focal positivity; } \\
\text { SMA and S100 }\end{array}$ & $\begin{array}{l}\text { Desmin } \\
\text { ER, PR } \\
\text { Variable; CD34 and } \\
\text { SMA }\end{array}$ & $\begin{array}{l}\text { Variable; } \\
\text { ER, PR } \\
\text { CD34 } \\
\text { SMA }\end{array}$ & $\begin{array}{l}\text { ER, PR } \\
\text { CD34 } \\
\text { Desmin } \\
\text { SMA }\end{array}$ & $\begin{array}{l}\text { Desmin } \\
\text { ER, PR } \\
\text { Variable; CD34 and } \\
\text { SMA }\end{array}$ \\
\hline \multirow{2}{*}{ Negative IHC } & $\begin{array}{l}\text { Cytokeratin } \\
\text { Myoglobin }\end{array}$ & $\begin{array}{l}\text { Cytokeratin } \\
\text { S100 }\end{array}$ & \multirow{2}{*}{$\begin{array}{l}\text { Desmin } \\
\text { S100 }\end{array}$} & \multirow{2}{*}{$\begin{array}{l}\text { Cytokeratin } \\
\text { S100 }\end{array}$} & \multirow{2}{*}{$\begin{array}{l}\text { Myogenin } \\
\text { Myo D1 }\end{array}$} \\
\hline & $\mathrm{CD} 34$ & & & & \\
\hline Treatment & Local excision & $\begin{array}{l}\text { Surgical excision } \\
\text { \& Adjuvant } \\
\text { chemotherapy }\end{array}$ & Local excision & Local excision & Simple excision \\
\hline
\end{tabular}


Histogenesis and pathogenesis of angiomyofibroblastoma have not been eluciated yet. However, some authors suggested that the neoplasm is probably derived from primitive mesenchymalcells of subepithelial myxoid stroma which may undergo differentiation to myofibroblasts under hormonal stimuli (12). The relationship between AMFB and tamoxifen which is used in treatment of breast cancer was firstly determined by Varras et al (7). In this study, it has been suggested that tamoxifen treatment may cause proliferation in mesenchymal cells of the vagina by estrogenic stimulation. Due to this effect, it has been reported to increase the incidence of endometriosis, adenomyosis, endometrial hyperplasia, leiomyoma, ovarian cysts, cervical and endometrial polyps especially in postmenopausal patients (7). Other previous studies have shown that in breast cancer patients, tamoxifen and similar drugs cause the development of vaginal AMFB $(7,12-15)$. Although AMFB of the cervix is rare, cervical AMFB is much rarer due to tamoxifen and only 1 case has been reported in the literature so far.

\section{CONCLUSION}

Angiomyofibroblastoma located in uterine cervix is an unusual case, which creates a challenging diagnosis. The ethio-pathogenesis of AMFB is not clear yet. There are cases supporting the claim that says hormonal stimulation and usage of tamoxifen might have an effect on AMFB development. Since in our case the breast carcinoma is triple negative, there is no history of tamoxifen usage. As a result, more studies are needed to be made in order to show the relation between tamoxifen and AMFB development.

\section{ETHICAL DECLARATIONS}

Informed Consent: Written informed consent was obtained from all participants who participated in this study.

Referee Evaluation Process: Externally peer-reviewed.

Conflict of Interest Statement: The authors have no conflicts of interest to declare.

Financial Disclosure: The authors declared that this study has received no financial support.

Author Contributions: All of the authors declare that they have all participated in the design, execution, and analysis of the paper, and that they have approved the final version.

\section{REFERENCES}

1. Lee CL, Ng BK, Nurismah MI, Chew KT, Aruku N, Lim P. Concurrent utero-vaginal prolapse with cervical angiomyofibroblastoma : a rare disease with distinct entity. J Surg Acad 2015; 5: 58-61
2. Min JK, Ji NK, Lindsay Ji HS, Chang Lim Hyun SSS, Chul Min Park SYK. Angiomyofibroblastoma of the uterine cervix in a breast cancer patient: A case report. Korean J Obstet 2011; 54: 330.

3. Fletcher CD, Tsang WY, Fisher C, Lee KC CJ. Angiomyofibroblastoma of the vulva. A benign neoplasm distinct from aggressive angiomyxoma. Am J Surg Pathol 1992; 16: 373-82.

4. Babala P, Bíró C, Klačko M, Mikloš P, Ondruš D. Angiomyofibroblastoma of the cervix uteri: a case report. Klin Onkol 2011; 24: 133-6.

5. Wong YP, Tan GC, Ng PF. Cervical angiomyofibroblastoma: a case report and review of literature. J Obstet Gynaecol (Lahore) 2017; 37: 681-2.

6. Roncati L, Pusiol T, Piscioli F, Barbolini G MA. Undetermined cervical smear due to angiomyofibroblastoma of the cervix uteri. J Obstet Gynaecol (Lahore) 2017; 37: 829-30.

7. M Varras, C Akrivis, A Demou, E Kitsiou N Antoniou. Angiomyofibroblastoma of the vagina in a postmenopausal breast cancer patient treated with tamoxifen : clinicopathologic analysis of a case and review of the literature. Int J Gynecol Cancer 2006; 581-5.

8. Weis SW GJ. Enzinger and Weiss's Soft Tissue Tumors. 4th ed. St. Louis: Mosby. In: Enzinger and Weiss's Soft Tissue Tumors 4th ed St Louis: Mosby 2001. p. 695-723.

9. Steeper TA, Rosai J. Aggressive angiomyxoma of the female pelvis and perineum. Report of nine cases of a distinctive type of gynecologic soft-tissue neoplasm. Am J Surg Pathol 1983; 7: 463-75.

10. Salman MC, Kuzey GM, Dogan NU, Yuce K. Aggressive angiomyxoma of vulva recurring 8 years after initial diagnosis. Arch Gynecol Obstet 2009; 280: 485-7.

11. Laskin WB, Fetsch JF, Tavassoli FA. Myofibroblastoma: fourteen cases of a distinctive mesenchymal tumor arising from the specialized subepithelial stroma of the lower female genital tract. Hum Pathol 2001; 32: 715-25.

12. Salman MC, Ureyen I, Tanas O, Baydar DE, Yuce K. Possible Relationship Between Tamoxifen Therapy and Vaginal Angiomyofibroblastoma. UHOD 1992; 49-52.

13. Lee H, Jang KY, Park HS, et al. Angiomyofibroblastoma of the vagina in a breast cancer patient. Pathology 2008; 40: 534-6.

14. Kumasaka T, Mitani K, Shiotsu H, Kato H, Joho M, Suda K. Vascular endothelial growth factor expressed by mast cells rather than tumour cells in angiomyofibroblastoma of the vaginal wall. Histopathology 2007; 51: 557-9.

15. Saleh MM, Yassin AH, Zaklama M. Recurrent angiomyofibroblastoma of the vagina: a case report. Eur J Gynaecol Oncol 2007; 28: 324. 